\title{
Pazarlama Halkla İlişkilerinde Transmedya Hikâyeciliği Uygulamaları: Turkcell "Emocanlar" Kampanyası Örneği *
}

\section{Transmedia Storytelling Practices In Marketing Public Relations: The Sample of Turkcell "Emocanlar" Campaign}

\author{
Merve Çalık ${ }^{a}$, Feridun Nizam ${ }^{\text {b** }}$ \\ ${ }^{a}$ Fırat Üniversitesi Sosyal Bilimler Enstitüsü İletişim Bilimleri ABD. Elazığ/Türkiye. \\ ORCID: 0000-0002-8040-5352

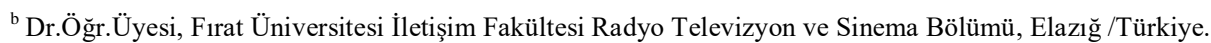 \\ ORCID: 0000-0002-4215-6973
}

\section{MAKALE BİLGISİ}

Makale Geçmişi:

Başvuru tarihi: 01 Ocak 2020

Düzeltme tarihi: 15 Mayıs 2020

Kabul tarihi: 21 Mayis 2020

Anahtar Kelimeler:

Transmedya Hikâyeciliği

Pazarlama Halkla İlişkiler

Reklam

\section{ART ICLE INFO}

Article history:

Received 01 January 2020

Received in revised form 15 May 2020

Accepted 21 May 2020

\section{Keywords:}

Transmedia Storytelling,

Marketing Public Relations

Advertising
ÖZ

Bu çalışmada transmedya hikâyeciliğinin pazarlama ve halkla ilişkilerde kullanımı; marka imajı ve marka farkındalığı oluşumunda çoklu ortamda yapılan uygulamaların hedef kitlenin genişlemesinde nasıl etkili olduğu, hikâye oluşturulurken konunun hangi temalar ve hangi karakterler ile anlatılmaya çalışıldığı soruları bağlamında "Turkcell Emocanlar" kampanyası örneğiyle analiz edilmiştir. Çalışmada tüketici açısından transmedyal anlatı kullanılarak yürütülen pazarlama ve halkla ilişkiler faaliyetlerinde marka farkındalığı oluştuğu, tüketicinin hikâyeye katılması ile diyalojik iletişim ortamının arttığı ve marka ile aralarında özel bir bağ oluştuğu sonucuna ulaşılmıştır. Marka açısından ise transmedya hikâyeciliği ile hedef kitlesini genişleten markanın pazar payını arttırdığı, hikâye oluşumunda seçilen karakterlerin tüketicilerle ne kadar çok benzer yönleri olursa hikâyenin daha çok benimsenip rakipleri arasından sıyrılarak dikkat çekmesine olanak sağladığı tespit edilmiştir.

\section{A B S T R A C T}

In this study, the use of transmedia storytelling in marketing and public relations was analyzed by Turkcell Emocanlar campaign, in the context of the questions of how multi-media applications in the formation of brand image and brand awareness were effective in the expansion of the target audience, with which themes and with which characters the subject was tried to be explained while creating the story. In the study, it was concluded that brand awareness was created in the marketing and public relations activities carried out by using the trans-media narrative for the consumer, the dialogical communication environment increased with the participation of the consumer in the story and a special bond was formed between them and the brand. In terms of the brand, it has been determined that the brand, which expands its target audience with its transmedia storytelling, has increased its market share, and the more similarities the characters selected in the story formation have with the consumers, the more the story allows to be adopted and stand out from its competitors.

\section{Giriş}

Kalabalık bir pazarda aynı olan markaların dikkat çekmeyi bırakın sıradan olmaya başladığı görülmektedir. Rakipleri ile aynı olmaya çalışan markaların bir süre sonra unutulup/silinip gitmesi buna karşılık farklı olanın ise

daima dikkat çekmesi, konuşulur olmasıyla birlikte varlığını sürdürmesi kaçınılmazdır. Çünkü günümüz tüketim ortamında artık markaların ya da pazarlamacıların değil tüketicilerin ne istedikleri, hangi markalara kulak verdikleri, markaya ne kadar zamanını ayırdığı, markayla arasında bir bağ kurup kurmadığı önemli hale gelmiştir.

\footnotetext{
*Bu çalışma birinci yazarın 2019 yılında Dr.Öğr.Üyesi Feridun NIZAM danışmanlığında Fırat Üniversitesi Sosyal Bilimler Enstitüsü İletişim Bilimleri Anabilim Dalı'nda yürüttüğü 'Turkcell 'Emocanlar' Örneğiyle Pazarlama Halkla İlişkilerinde Transmedya Hikâyeciliği Uygulamaları" başlıklı yüksek lisans tezinden türetilmiştir.

** Sorumlu yazar/Corresponding author

e-posta: fnizam@ firat.edu.tr
} 
Tüketicilerin bu tutum değişikliği ve taleplerine cevap vermek amacıyla transmedya hikâyeciliği kavramı ortaya çıkmıştır. Tüketiciler ile ortak hareket eden onların markaya katkıda bulunmasını sağlayan "transmedya hikâye anlatıcılığı" son zamanlarda kullanımı giderek artan kavramlardan ve uygulamalardan biri olmaya başlamıştır. Ülkemizde uygulamalarına yeni yeni rastlanan bu anlatı stratejisi ile ilgili literatürdeki çalışmalar da yeni yeni ivme kazanmaktadır. Bu çalıșmada transmedya hikâye anlatıcılığı, mevcut çalışmalardan farklı olarak, pazarlama halkla ilişkiler bağlamında bir reklam kampanyası içeriğindeki uygulama örnekleriyle analiz edilmiştir.

Araştırmada, transmedya hikâye anlatımının pazarlama ve halkla ilişkiler açısından değerlendirilmesinin ardından, yapılan kampanyalar ele alınırken, marka imajı ve marka farkındalığı oluşturmada transmedyanın önemi, çoklu ortamda yapılan uygulamaların hedef kitlenin genişlemesinde nasıl etkili olduğu, hikâye oluştururken konunun hangi açıdan ve hangi karakterler ile anlatıldığının açıklanması üzerinde durulmuştur.

\section{Transmedya Hikâyeciliği (Kavramsal Çerçeve Ve Mevcut Çalışmalar)}

\subsection{Transmedya Hikâyeciliği}

Transmedya hikâyeciliği, kavramı literatüre kazandıran Henry Jenkins'in ifadesiyle; “ideal transmedya hikâye anlatım biçiminde, her medya ortamı en iyi yaptığı şeyi yapar - bir filmde bir hikâye tanıtılabilir, televizyon, romanlar ve çizgi romanlar yoluyla dünyası oyun yoluyla keşfedilip deneyimlenebilir” (Jenkins, 2003).

Transmedya hikâye anlatımı, "medyanın yakınsamasına yanıt olarak ortaya çıkan yeni bir estetiğe atıfta bulunur tüketicilere yeni talepler yükleyen ve bilgi topluluklarının aktif katılımına dayanan bir estetik. Transmedya hikâye anlatımı, dünya yaratma sanatıdır. Herhangi bir kurgusal dünyayı tam olarak deneyimlemek için tüketiciler, avcı ve toplayıcı rolünü üstlenmeli, medya kanallarında hikâyenin parçalarını takip etmeli, çevrimiçi tartışma grupları aracılığıyla birbirleriyle karşılaştırmalı ve işbirliği yapmalıdır" (Jenkins, 2006: 21).

Transmedya hikâyeciliği, en basit tanımı ile (Sarı, 2017: 71); "bir hikâyenin, televizyon, film, çizgi roman, animasyon, mobil pazarlamalı sunumlar ve sosyal medya gibi birden fazla platformda sunulmasıdır”.

Terim olarak incelendiğinde "trans" ve "medya" olmak üzere iki ayrı kelimenin birleşiminden meydana geldiği görülmektedir. "Trans" ön eki "ötesinde, aşırı, karşı tarafta, arasından, içinden, tamamen, bütün ve çapraz vari" anlamlarında ve "medya" kelimesi ise iletişim ortamları anlamında ve İngilizcede "ortam, araç, kanal" anlamına gelen "medium" kelimesinin çoğulu olan "media" kelimesinden gelmektedir (Gürel ve Tiğl1, 2013:44).

Transmedya hikâye anlatıcılığında bir içeriğin birden fazla platformda görülmesi ile hedef kilenin etkileşimini de içeren anlatı tarzı ile aynı içerik farklı platformlarda paylaşılarak hedef kitlenin sayısı arttırılmaktadır. Hikâye farklı platformlarda yer alıp daha çok konuşulmakta ve hedef kitlenin ilgisi çekilmektedir. Instagram hesabından, Facebooktan ve çeşitli bloglardan yapılan yorumlar ile ilgi artmakta ve kitabının da basılması ile öykünün yayılma ve bilinirliği artmaktadır (Bolat, 2018: 323).

Buradan da anlaşılacağı gibi transmedya, geleneksel ve yeni medya araçlarını içerisinde barındıran, birlikte kullanımına ortam hazırlayan bir anlatı stratejisidir. Nitekim çalışmamızın konusunu oluşturan Turkcell Emocanlar kampanyasında da geleneksel mecraların yanı sıra eş zamanlı olarak yeni medya mecraları da kullanılmıştır.

Transmedya hikâye anlatımının ne olduğunu özetlemek gerekirse, Pratten'in ifadesiyle transmedya hikâye anlatıcılığının üçlüsü, 3 C'si olarak adlandırdığı; characters /karakterler, convenience/kolaylık, uygunluk ve community/ topluluk unsurlarını entegre etmeyi amaçlayan ve kitle katılımını sağlayan bir yaklaşımdır. Bu doğrultuda üç temel transmedya hikâye anlatımı unsurunun detayları şu şekildedir (Pratten, 2015:11):

Karakterler: Kullanıcıların hikâye ile etkileşimini sağlayarak hikâyenin önemini artırmak ve katılımcıları hikâyenin içerisine çekebilmektir. Çalışma konumuzu oluşturan Emocan reklam karakterlerine baktığımız zaman 7 emocan karakterinin her birinin farklı katılımcı kitlesine hitap ettiği görülmektedir. Bu sayede marka oluşturduğu karakterler sayesinde hikâyesini farklı gruplardan hedef kitlelere ulaştırmaktadır.

Uygunluk: Doğru içeriği, doğru zamanda, doğru kişilere sunmanın önemi büyüktür. İçerikler oluşturulurken hedef grupların sosyo-kültürel ve sosyo-ekonomik yapılarının göz önünde bulundurulması gerekmektedir. Ayrıca içeriklerin hedef gruplarla buluşturulması noktasında zamanlamaya dikkat etmek gerekmektedir. Nitekim günümüzde sosyal medyanın da etkisi ile yazılı ve sözel kültür neredeyse yerini emojilere bırakmaktadır. $\mathrm{Bu}$ altyapı üzerinde inşa edilen "Emocan" adlı karakterlerin her birinin kendine ait farklı özellikleri ile farklı sosyo-kültürel ve sosyoekonomik yapıdaki hedef kitleye ulaşmayı amaçladığı görülmektedir. Reklam filmlerinde de emocanların bulundukları ortamlar ve konuşmaları bu durumu destekler niteliktedir. Ayrıca emocanların kendine has yaptıkları burç yorumlarının yeni yıldan önce sunulması vb. örneklerde zamanlamaya dikkat edildiği ve içeriğin uygun zamanlarda hedef kitle ile paylaşılmaya çalışıldığını söyleyebiliriz.

Topluluk: Fanların birbiriyle bağlantı halinde olması ve onların ödüllendirilmesi büyük önem taşımaktadır. Sanal topluluk içerisinde kullanıcıların birbirleriyle etkileşiminin olması ve teşvik edici ödül unsurlarının bulunması, içeriğin daha fazla kişiye ulaşmasını sağlayabilmektedir. Nitekim çalışma konumuzu oluşturan Turkcell markasının takipçileri site ve forumlar üzerinden kendi aralarında yaptıkları yorumlarla etkileşim sağlamaktadır. Örneğin Salla Kazan uygulaması ile kullanıcılara çeşitli görevler vererek ödüllendirmesi markanın hedef kitle ile ilişkisini daha farklı bir boyuta taşımasına olanak sağlamıştır. 
Görsel 1. Transmedya Hikâye Anlatımı Üçlüsü

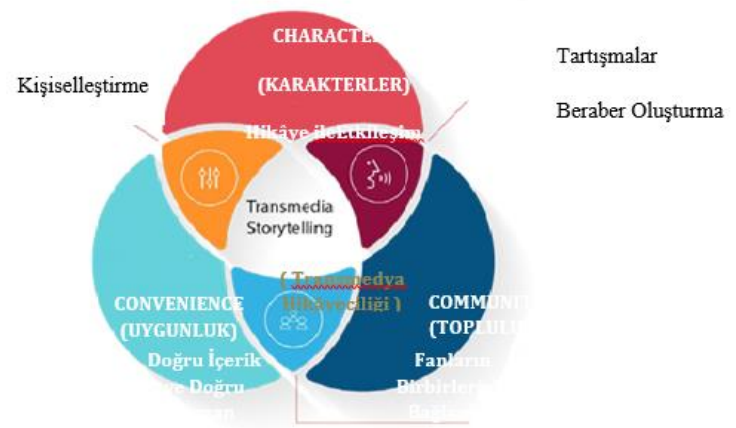

Gruplar, Fraksiyonlar, Lonca ve Takımlar Hediye ve Paylașım

Kaynak: (Pratten, 2015: 12).

Görselde yer aldığı üzere kesişim noktalarında gereken eylemler ve işlevler doğrultusunda transmedya hikâye anlatımının şekillendirilmesi gerekmektedir:

Karakterler + Uygunluk: Her insan için hikâye deneyimlerinin dünyayla ilişkilerine dayanarak kişiselleştirilmesi önemlidir. Hikâye ile etkileşim halinde olan bireylerin, doğru içeriğe, doğru zamanda maruz kalarak hikâyeyi kişiselleştirmesi ve hikâyenin bir parçası haline gelmesi, transmedya hikâye anlatımının en önemli yönlerindendir.

Uygunluk + Topluluk: Uygun içeriklerin fan gruplarının ilgisini çekmesi, bu içerikler sayesinde grupların birbirleriyle bağlantı kurması ve devamlı etkileşim halinde olması ile grup üyelerinin birbirini yönlendirmesi transmedya hikâyeciliğinin bir diğer önemli özelliğidir.

Topluluk + Karakterler: Toplulukların, fanların, içerik oluşturucuların hikâyeler ile etkileşim halinde olarak tartışmalar oluşturmaları veya yine içerikler geliştirmeleri gibi firsatlar sağlayan transmedya hikayeciliği online ilişkilerin gelişmesini ve web etkileşimli ve eğlenceli öğrenme sürecini gerçekleştirmesi açısından önemi her geçen gün artmaktadır.

Scolari'ye göre "transmedya anlatım hem dil (kitap, dergi, gazete, fotoğraf vb.), hem de kitle iletişim araçlarını (animasyon, televizyon, radyo, sosyal medya, video oyunları vb. ) kullanarak yayılan bir hikâye anlatım biçimidir (Scolari, 2009: 587)”. Araştırma konumuz Turkcell Emocanlar kampanyasında da transmedya örneği oluşturarak, dergi, gazete, televizyon, radyo, sosyal medya, video oyunları gibi çeşitli platformları kullanmış, hikâye genişleyerek çeşitli gruplar ile etkileşim sağlanmıştır.

\subsection{Transmedya Hikâyeciliği Alanyazını (Mevcut çalışmalar)}

Literatürümüzde yeni bir kavram olan transmedya hikâyeciliği çalışmalarından bir kısmının bulgularına ve kaleme alınmış bu eserin mevcut çalışmalardan farklı yönlerine kısaca değinilmiştir.

Dönmez ve Güler'in (2016:155-175) “Transmedya Hikâyeciliği 'Doritos Akademi' Örneği”' adlı çalışmasında Doritos Akademi reklam kampanyası araştırılmıştır. Pazarlama stratejisi olarak transmedya kampanyalarının kullanılmasının markalara olan katkısı ve transmedya kampanyaları ile geleneksel kampanyalar arasındaki farklılıkların ortaya konulduğu çalışmada marka hikâyesinin halkla ilişkiler kapsamında şirketlere sağladığ yararlara değinilmemesi geleneksel halkla ilişkiler kampanyalarından farklı olarak halkla ilişkiler uygulaması olarak reklam kampanyalarında transmedyal anlatı uygulamalarının incelendiği çalışmamız bu noktada farklılaşmaktadır.

Sarı'nın (2017: 71)“Transmedya Hikâye Anlatıcılığı: Kötü Çocuk Örneği” çalışmasında internet tabanlı bir platform olan Wattpad'de yer alan Kötü Çocuk adlı hikâye incelenmiştir. Kitap endüstrisinde transmedya uygulamasına bir örnek olan bu çalışmadan farklı olarak çalışmamızda bir reklam kampanyası incelenerek transmedyal anlatının pazarlama ve diyalojik iletişim açısından önemi açıklanmaktadır.

Çetinkaya, (2017: 559)“Marka Sadakati Oluşturma Aracı Olarak Transmedya Hikâye Anlatımının Yeri ve Değeri" adlı çalışmasında transmedya hikâye anlatıcılığını marka sadakati oluşturmak ve marka deneyimi bağlamında değerlendirmeyi amaçlamaktadır. Tansmedya hikâyeciliğinin marka ve marka sadakati ile ilişkisini göstermek amacıyla gerçekleştirilen bu araştırmadan farklı olarak örnek olay incelemesi yapılarak pazarlama ve halka ilişkiler alanında uygulanması incelenecektir.

Bayraktar, (2018: 325) "Moda Sektöründe Transmedya Hikâye Anlatımı: Barbie Bebek Transmedya Uygulamaları Örneği” çalışmasında Barbie ürünleri ve Barbie'nin moda ile olan ilişkisini transmedyal anlatı stratejileri temelinde açıklamaya çalışmıştır. Söz konusu çalışmada transmedyal anlatının pazarlama faaliyetlerinde uygulanması ile hikâyenin daha çok platforma yayıldığı ve marka bilinirliğini arttırdığı, barbie bebeklerin oyuncak olmalarının ötesinde markaya olan katkıları moda alanı üzerinden anlatılmakta, yapacağımız çalışmada ise Emocan olarak adlandırılan transmedya hikâye karakterlerinin markaya olan katkısı, marka farkındalığı oluşturmadaki etkisi pazarlama ve halkla ilişkiler kapsamında incelenecektir.

Aktan'ın (2018:23)“'Sosyal Ağlar ve Transmedya Hikayeciliği: Kullanıcı Paylaşımları Üzerinden Transmedyal Hikâye Etkinliğinin Değerlendirilmesi” adlı çalışmasında Facebook üzerinden incelemeler yapılmıştır. Çalışmamızda farklı olarak televizyonda başlayan transmedyal hikâyenin, sosyal medya, mobil oyun, oyuncak vb. ortamlarda nasıl uygulandığı ve yayılarak markanın hedef kitle ile nasıl etkileşim içerisinde olduğu incelenmiştir.

Çakmak (2018: 69)“Dijital Oyunlar ve Transmedya Hikâyeciliği" çalışmasında dijital oyunlar ve transmedya hikâyeciliği arasındaki ilişkiyi inceleyerek transmedya uygulamalarını örneklerle açıklamaya çalışmıştır. Söz konusu çalışma ile oyunların transmedya kapsamında kitap veya filme dönüşümü incelenmiş olup oyun ortamlarında transmedya hikâye anlatıcılığı uygulanması gösterilmiştir. Çalışmamızda ise farklı olarak markaların transmedyal hikâye evrenini genişletmek için reklam kampanyalarını mobil oyun uygulamalarına dönüştürdükleri, bu sayede hedef kitlelerini nasıl genişlettikleri gösterilmeye çalışılmıştır. 
Duğan (2018: 193) "Transmedya Hikâye Anlatımının Halkla İlişkilerde Kullanımı" çalışmasında transmedya hikâyeciliğinin halkla ilişkiler alanında nasıl kullanıldığını ve halkla ilişkiler için transmedya hikâyeciliğinin önemini ortaya koymaya çalıșmıştır. Söz konusu çalışmada halkla ilişkilerde transmedyal anlatının sponsorluk ve tanıtım uygulamalarında kullanımı ele alınmış fakat reklam kampanyası ile ilişkisi incelenmemiştir. Reklam kampanyasında transmedya hikâye anlatıcılığının pazarlama odaklı halkla ilişkiler kapsamında incelendiği çalışmamız bu noktada Duğan'dan farklılaşmaktadır.

Koçyiğit'in (2018: 217) "Dijital Çağın İletişim Sanatı: Transmedya Hikâyeciliği ve Dijital Halkla İlişkiler" adlı çalışmasında transmedya hikâye anlatıcılığı ve markalaşma, transmedya hikâyeciliği ve dijital halkla ilişkiler kavramları incelenmiştir. Çalışmadan farklı olarak "Turkcell Emocanların" örnek olarak incelendiği çalışmamızda markanın pazarlama odaklı halkla ilişkiler stratejisinde transmedya hikâye anlatıcılığını uygulama biçimi incelenmiştir.

Ahmet Koçyiğit (2018:255) "Transmedya ve Dijital Reklam Anlatısı" çalışmasında transmedya ve dijital reklam ilişkisini incelemiştir. Kitle iletişim teknolojilerinin değişmesi ile reklamcılık faaliyetlerinin de değiştiği üzerinde durulan söz konusu çalışmadan farklı olarak gelişen teknoloji ve internet ağlarının insan hayatında giderek artan yerinin geleneksel pazarlama ve halkla ilişkiler stratejilerinde de nasıl değișikliklere neden olduğu transmedya hikâye anlatıcılığı üzerinden incelenmiştir.

Nizam ve Çalık’ın (2018: 325) "Transmedya Hikâyeciliği Bağlamında 'Söz' Dizisinin Analizi” adlı çalışması literatürdeki mevcut eserlerden farklı olarak televizyon dizisini ele almıştır. Söz konusu çalışma dizilerde transmedyal anlatım uygulamasına örnek oluşturmakta iken Turkcell Emocanlar konulu bu çalışma ise reklam ve transmedya kavramları üzerinden bir reklam kampanyası incelenmesi yönüyle farklılaşmaktadır.

Konu ile ilgili yapılan tez çalışmalarını da değerlendirecek olursak Filiz Akbaba Resuloğlu tarafindan yazılan (2014) "Yakınsama Kültürü ve Transmedya Hikâye Anlatımı Uygulamaları Üzerine Bir Çözümleme: Propp'un İşlevler Kuramı ve Taht Oyunları (Game Of Thrones ) Dizisi" isimli yükssek lisans tez çalışması Türkiye'de bu konudaki ilk lisansüstü çalışmadır. Çalışma ile dizilerde transmedya kullanımı incelenmiştir. Reklam kampanyalarında transmedya hikâye anlatımını incelemesi açısından çalışmamız farklılaşmaktadır.

Mevlüt Dönmez tarafindan yazılan (2015) "Pazarlama İletişiminde Transmedya Uygulamaları: Örnek Olay İncelemeleri" adlı yüksek lisans tez çalışması kapsamında niteliksel bir araştırma gerçekleştirilerek Türkiye'de transmedyal anlatım kullanılarak yapılan reklam kampanyaları incelenmiştir. Çalışma konumuzda da bir reklam kampanyası incelenecek olsa da söz konusu çalışmada, transmedyal anlatının pazarlama iletişimininde kullanımı, transmedya kampanyalarının markalara olan katkısının ortaya koymaya çalışmış halkla ilişkiler ile olan ilişkisine değinilmemiştir. Halkla ilişkiler kapsamında transmedyal anlatının markaya katkısının incelenmesi bakımından çalışmamız farklılaşmaktadır.
Bir diğer tez çalışması Ramazan Ramazanov Hüseynoğlu tarafından yazılan (2016) "Transmedya Hikâye Anlatımının Kullanıc Kitle İle Ortak Üretimi: Beyazıt Akman'ın 'İmparatorluk III' Romanının Tanıtım Filmi” adlı yüksek lisans tez çalışmasıdır. Sinema filminde trasmedyal anlatının kullanılması ile hedef kitlenin pasif kullanıcı konumundan çıkarak nasıl üreten tüketici konuma geçtiği gösterilen çalışmadan farklı olarak hedef kitle ile markanın etkileşimi film örneklemi üzerinden değil transmedyal pazarlama ve reklam kampanyası üzerinden anlatılmaya çalışılacaktır.

Ali Karpuz tarafindan yazılan (2017) "Transmedya Markalama ve Etkileşimli Reklam İlişkisi” adlı yüksek lisans tez çalışmasında ise; transmedya markalama ve etkileşimli reklam ilişkisi ele alınmıştır. Transmedyanın marka ve reklam ilişkisini incelendiği çalışmada hedef kitle ile ilişkileri kolaylaştırdığı belirtilmiş olsa da, hedef kitle ile olumlu ilişkiler oluşmasını sağlayan halkla ilişkiler ve transmedya ilişkisine değinen çalışmamız bu noktada farklılaşmaktadır.

Huri Deniz Karcı tarafindan yazılan (2018) "Markalaşma ve Transmedya Hikâyeciliği: Bir Uygulama Örneği”" adlı doktora tezi ise transmedya hikâyeciliğinin markalaşmada kullanılmasının marka ve tüketici açısından ne gibi sonuçları olabileceğini göstermek amaciyla gerçekleştirilmiştir. Söz konusu çalışmada markalaşma ve marka sadakati oluşturmada transmedya hikâyeciliğinin etkisi incelenmiştir halkla ilişkiler ile olan ilgisine değinilmemiştir, çalışmamız bu noktada farklılaşmaktadır.

Yukarıda incelediğimiz çalışmalara bakıldığında transmedya hikâye anlatıcılığının, kitaptan reklama, pazarlamadan modaya, sosyal medyadan dijital oyun endüstrisine kadar çeşitli alanlarda açıklanmaya çalışıldığ görülmektedir. Araştırmamızı farklı kılan nokta ise yeni bir uygulama alanı olan transmedyanın pazarlama halkla ilişkiler bağlamında reklam kampanyasında uygulanmasını incelemesidir. Çalışma kapsamında transmedya hikâye anlatıcılığını pazarlama halkla ilişkiler alanında incelemeye çalışacağımızdan halkla ilişkiler, pazarlama, pazarlama halkla ilişkileri vb. kavramlara da kısaca değinmek yararlı olacaktır.

\section{Pazarlama Amaçlı Halkla İlişkiler- Marketıng Public Relations (MPR)}

Marketing Public Relations (MPR), yaygın olarak kullanılmasına rağmen bu kavram dilimizde; pazarlama halkla ilişkileri, pazarlama yönelimli halkla ilişkiler, pazarlama amaçlı halkla ilişkiler olarak aktarılmıştır.

Ülkemizde 90'lı yılların başından itibaren kullanılmaya başlanılan MPR; reklam maliyetlerindeki artış, reklam kargaşası içinde mesajın etkisinin azalması ve reklamın tek başına yeterli etkide bulunamaması gibi nedenlerden ötürü önem kazanmıştır.

Pazarlama halkla ilişkileri, mesaja doymuş bir toplumda sadece güçlü değil, aynı vakitte diğer iletişim uygulamalarına kıyasla daha etkili ve iyi bir seslenme şeklidir. İnsanların beyinleriyle kalplerine ulaşma noktasında hedef kitlelere ulaştırıldığında daha etkili olmaktadır. İşletmeler açısından da aynı zamanda maliyeti daha düşüktür. Şirketler çeşitli kültürel etkinliklere 
sponsorluk yaptıklarında veya çeșitli toplumsal amaçlara hizmet etmek için para bağışında bulunduklarında hem kitlelerin dikkatini çekmekte hem de halkın saygısını kazanmaktadır. Haber niteliğindeki olayların, yayınların, sosyal yatırımların, çevre ile ilișkili konuların vb. şekildeki toplumsal konuların yaratıcı kullanımıyla pazarlama amaçlı halkla ilişkiler, şirketlere ve kurumlara rakiplerinin arasından sıyrılma, ürünleri ile öne çıkma firsatı sağlamaktadır (İpekli, 1994: 8).

Gün geçtikçe önem kazanan Pazarlama Halkla İlişkileri özellikle aşağıda belirtilen pazarlama hedeflerine ulaşmada büyük firsatlar sunmaktadır (Büyükbaykal, 2012: 560-561).

\section{$\checkmark \quad$ Piyasaya yeni ürünleri/hizmetleri sürmek}

$\checkmark$ Mevcut olarak piyasada yer alan ürünlerin/hizmetlerin yeniden hatırlatılmasını ya da yeniden bir ambalaj içinde sunulmasını, pazar içinde yeniden pozisyon oluşumunu sağlamak

$\checkmark$ Eskiden var olan ürünlerin yeni faydalarını insanlara iletmek, eski ürünlerin/hizmetlerin yeni kullanım alanlarının promosyonunu yapmak

$\checkmark$ İnsanların ürün ve hizmetlerle tanışmasını ve kaynaşmasını sağlamak

$\checkmark$ Yeni pazarlar açmak, ikincil pazarlara erişmek, zayıf pazarları güçlendirmek

$\checkmark$ Reklama karşı müşterilerin direncini kırmak, reklam mesajlarını güçlendirerek iddiaların haklılığını kanıtlamak, böylece reklama destek olmak

$\checkmark$ Reklamı yapılamayacak ürünlerin/hizmetlerin tanıtımını sağlamak

$\checkmark \quad$ Satış geliştirme kampanyalarını güçlendirmek

$\checkmark$ Pazarlamacılar ile pazarlama amaçlarının ulaşmak istediği son noktaları negatif olarak etkileyebilecek olaylar arasındaki iletişim kanallarını açık tutmak

$\checkmark$ Herhangi bir risk durumunda ürünü /hizmeti savunmak

$\checkmark \quad$ Satış gücünü motive etmek, desteklemek,

$\checkmark$ Dağıtımcıların ve ara kanalların desteğini kazanmak.

Pazarlama Halkla İlişkilerinin bunun yanı sıra başlıca avantajları ise şu şekilde açıklanabilir:

$\checkmark$ Reklamdan daha ucuz ve hesaplıdır, daha da etkindir

$\checkmark$ Pazarlama halkla ilişkileri ilettiği mesajlar reklam kargaşası ve karmaşası içinde etkinliği azalan diğer mesajlardan sıyrılır, ön plana çıkarır

$\checkmark$ Reklam kampanyası bütünler; Pazarlama halkla ilişkileri reklamda kullanılan, verilen mesajların inanılırlığını arttırarak, pekiştirerek reklam kampanyasını bütünler

$\checkmark \quad$ Daha etkindir. Başarılı bir şekilde yürütülerek bir pazarlama halkla ilişkiler planı 15-30 saniyelik bir televizyon reklamına kıyasla daha fazla ürün bilgisinin hedef kitlelere, tüketiciye ulaştırılmasını sağlar

$\checkmark$ Pazarlama halkla ilişkileri çalışmaları tüketici gözünde ürüne karşı daha inandırıcıdır. Pazarlama halkla ilişkileri planı çerçevesinde yapılacak bir çalışma her şeyden önce haber niteliği taşıdığı ve tarafsız üçüncü şahıslar tarafından iletildiği için reklamdan daha fazla inandırıcı olacaktır.

$\checkmark$ Pazarlama halkla ilişkileri çalışmaları satışı arttırır. Reklam ve satış geliştirme gibi pazarlama halkla ilişkilerinin satışı arttırma görevi vardır.

Pazarlama Halkla İlişkilerinin yukarıda saydığımız avantajlarına baktığımız zaman transmedya hikâyeciliğinin markaya olan katkısıyla benzer özellikler taşıdığını görmekteyiz. Transmedya hikâyeciliği marka ile hedef kitle arasında olumlu bir bağ oluşturmakta, farklı gruplara ulaşabilmeye imkân sağladığı için yeni pazarlara ulaşmak kolaylaşmaktadır. Hikâye oluşturularak hedef kitle hikâyenin içerisine çekilip reklamın bir parçası haline getirilir ve bu sayede markanın rakiplerinden daha çok dikkat çekmesi sağlanır. Buradan yola çıkarak transmedyal anlatının pazarlama halkla ilişkiler uygulamalarında kullanılabileceğini söyleyebiliriz.

\section{Araştırmanın Metodolojisi}

\subsection{Araștırmanın Önemi}

Günümüzde pasif izleyicinin yerini aktif izleyicinin alması ile birlikte pazarlama stratejileri de değișmiștir. Yenilikleri yakından takip eden markalar çağa ayak uydurmak ve hedef kitlesi ile bağ kurmak için transmedya hikâyeciliğini kullanmaktadırlar. İletişim çalışmalarında incelenmeye başlayan bu kavram ile ilgili çeşitli çalışmalar bulunmaktadır. Halkla ilişkiler ile kullanımı üzerine yapılmış çok fazla çalışma olmaması, yeni nesil pazarlama taktiği olarak kampanyalarda nasıl kullanıldığının değerlendirilmesi açısından, örneklem seçiminde yeni pazarlama aracı olarak kullanılan emojilerin hikâye oluşturma karakteri olarak kullanılmasının kampanyaya katkısının ele alınması ve ivme kazanmış olan transmedya çalışmalarına katkı sağlaması bakımından önemlidir.

\subsection{Araştırmanın Varsayımları}

Transmedya hikâye anlatımı ve halkla ilişkiler perspektifinde reklam kampanyalarını incelemeyi amaçlayan bu çalışmanın belirlenen varsayımları şunlardır;

1. Halkla ilişkiler aracı olarak transmedya hikâyeciliği kullanılması marka farkındalığı yaratmaktadır.

2. Reklam ve halkla ilişkiler kampanyalarında transmedyal anlatının kullanılması diyalojik iletişimi arttırmaktadır.

3. Transmedya hikâyeciliği pazar payını arttırmada etkili bir yöntemdir.

4. Transmedya hikâyeciliği stratejileri kullanan medya içerikleri kullanmayanlara oranla daha çok dikkat çekmektedir. 
5. Hikâye ve karakterler oluşturulurken hedef kitleye yakın, kendisine benzer karakterlerle oluşturulmuş transmedyal kampanyalar daha başarılı olmaktadır.

\subsection{Araştırmanın Evren ve Örneklemi}

Araştırmanın evrenini günümüzde transmedya hikâye anlatıcılığını pazarlama halkla ilişkiler (MPR) kampanyalarında kullanan markalar oluşturmaktadır. Bu markalar arasından "amaçlı örneklem" (Patton, 2015: 265) türlerinden biri olan "ölçüt örnekleme" yoluyla seçilen Turkcell Emocanlar kampanyası çalışmanın örneklemini oluşturmaktadır. Amaçlı örneklem, "bilgi açısından zengin vakaları, doğası ve özü itibariyle araştırma sorusunu aydınlatacak durumları, stratejik olarak seçmek için kullanilır (Patton, 2015: 265).

Ölçüt örneklem, araştırmaya konu olacak örnekleme belli bir kıstasın getirilmesiyle oluşturulur. Hangi olay, kişi ya da durumların çalışılacağına araştırmacı kendi karar verir ve ölçütü kendisi belirler. Ölçüt örnekleme kullanılan araştırmalarda gözlem birimleri belli niteliklere sahip kişiler, olaylar ya da durumlardan oluşturulabilir. Ölçüt örneklemenin mantığı, önceden belirlenmiş bir ölçütü karşılayan tüm durumları gözden geçirmek ve incelemek, böylece ölçüt durumlarını ölçütü göstermeyenler ile açıkça (veya örtük olarak) karşılaştırmaktır (Patton, 2015: 281).

$\mathrm{Bu}$ çalışmada da ölçüt olarak, pazarlama halkla ilişkiler kampanyasında transmedya hikâyeciliği kullanımı ve kampanyanın halen aktif devam ediyor oluşu ölçüt olarak belirlenmiș ve bu ölçütleri karşılayan Turkcell Emocanlar kampanyası örneklem olarak seçilmiş̧ir.

\subsection{Araştırmanın Kapsam ve Sınırlılıkları}

Araştırma pazarlama halkla ilişsiler alanını kapsamaktadır. Buna bağlı olarak kampanyada transmedya hikâyeciliği kullanımı ile sinırlıdır.

\subsection{Veri Toplama ve Verilerin Analizi}

Veri toplama aracı olarak nitel bir çalışma olduğu için daha önce transmedya konusundaki mevcut çalışmalar incelenerek, reklam ve transmedya ilişkisi analiz edilmiş̧ir. Sonrasinda Turkcell firmasinın "Emocanlar" temalı reklamları kaydedilerek, transmedya hikâyeciliğinde hangi stratejilerin kullanıldığı çözümlemeler yoluyla analiz edilmiştir.

\section{Pazarlama İletişimi ve Halkla İlişsilerde Transmedya Hikâyeciliği Olarak Turkcell Emocanlar Örneği}

\subsection{Transmedya Hikâye Anlatımı ve Halkla İlişkiler}

İnsanlar bebeklik dönemlerinden itibaren hikâyeler dinleyerek büyürler. Yaşları ilerledikçe dinleyici olmanın yanı sıra, kendi hikâyelerini de başkalarıyla paylaşmaya, hikâye anlatıcısı olmaya başlarlar. En önemlisi yaşanılan anılarını, olayları aktarırken hiçbir zaman sadece bilgi vermekle yetinmez; o anı betimler, hissettiklerini aktarırlar. Hikâye anlatımı, "otantik ve saf eğlenceli bir dil kullanarak dinleyiciye bağlanan ve ilham veren bir iletişim aracıdır. Genel olarak dinleyici ile bir bağ kurarak önemli iç görüler ve bilgiler paylaşmayı hedeflemektedir" (Engin, 2013: 12). İnsanları etkilemek için hikâye anlatmak, geçmişten beri etkili bir güçtür. Tarihte insanlar, birbirlerinin hayatlarını yönlendirmek için hikâyenin gücünü kullanmışlardır. Mağara adamları statü kazanmak için duvar resimleri yapmışlar, Şehrazat anlattı̆̆ masalların sonunu bir sonraki geceye bırakarak ölümünü erteleyip durmuştur. Ağızdan ağıza iletişimle ilgili bir kavram olması dolayısıyla da hikâye anlatıcısının inandırıcı olması önemlidir. İnsanlar daha fazla bilgi almaktan öte inanmak isterler. Bunun için insanların inanmalarını sağlayacak ve umutlarını canlandıracak anlamlı hikâyelere ihtiyacı vardır (Kaya, 2014: 331).

Hikâyelerin, hikâye anlatıcıllğının insanlar arasında bu kadar etkili olması, markalar için de kendi hikâyelerini oluşturma isteği doğurmuştur. Bir markayı rakiplerinden ayırmak için yapılabilecek, marka farkındalığı ve sadakati oluşturmak için en doğru hareket, bireylerin kararlarını verirken gerçekçi olmaktan daha çok duyguları ile hareket etmeye yatkın olduklarını unutmamaktır. Çünkü günümüzde markalar, insanların sadece ihtiyaçlarını gidermek için kullandıkları ürünleri temsil etmenin çok ötesine ulaştılar. İnsanlar artık sadece ihtiyaçlarını gidermekle kalmak istemiyor, çok daha büyük bir şeylerin parçası olmak istiyorlar. Hikâye anlatımı ise onlara parçası olmak isteyecekleri, bağ kurabilecekleri bir dünyanın kapısını açarak etkileyici bir maceraya başlama imkânı sunuyor.

Günümüze kadar yaşayan hikâye anlatımı, iletişim teknolojilerinin de gelişimiyle kendine yeni anlatı araçları bulmuştur. Yeni medya araçlarının ortaya çıkmasıyla beraber hikâye anlatımı daha hızlı ve anlatıcı katkısıyla birlikte genişleyen bir konuma gelmiştir. Günümüzün yeni iletişim araçlarıyla şekillenen hikâye anlatma yöntemi "transmedya hikâyeciliği" olarak literatürdeki yerini almıştır. Transmedya hikâye anlatıcılığının dünya yaratma sanatı olduğunu düşünen Henry Jenkins'e göre; "tüketicilerin bu dünyada avc1 ve toplayıcı rolüne bürünmesi, medya kanalları arasında hikâyenin parçalarının izini sürüp bulması, çevrimiçi tartışma grupları aracılığıyla birbiriyle notlarını karşılaştırması, zaman ve çabalarını ortaya koyan herkesin daha zengin bir eğlence deneyimi elde etmesini sağlamak üzere iș birliği yapması gerekmektedir" (Jenkins, 2016: 42-43).

Hikâyeyi en yoğun kullanan iletişim dallarının başında halkla ilişkiler gelir. Halkla ilişsiler küreselleşme ile birlikte disiplinlerin bir araya geldiği ve çok boyutlu çalışmaların yapıldığı bir bilim dalıdır bu yüzdende halkla ilişkiler hikâye üretim merkezi olarak tanımlanabilir (Aytemur, 2012: 100). Çağımızın hikâye anlatıcılığı olarak düşünebileceğimiz transmedya hikâyeciliği de önceleri kitap, oyun, film gibi alanlarda uygulanırken son zamanlarda pazarlama, halkla ilişkiler ve reklam gibi iletişim çalışmalarında kullanılmaya başlamıştır. Halka ilişkiler uygulayıcıları için transmedya hikâye anlatımı, oldukça cazip stratejik seçenekler sunar. Bir hikâyenin hem geleneksel hem de yeni iletişim araçlarında kamu ve paydaşlarına sunulması, örgütün hikâye anlatım sürecinde yaratıcı olmasını sağlar ve böylece örgüt ve hedef kitlesi arasında iletişim ve etkileşimi arttırır. "Halkla ilişkiler denilen ve kurumları, şirketleri medyanın hikâyeleri arasına yerleştiren sektör de aslında hikâye anlatıcılarının yoğun şekilde bulunması gereken bir yerdir. Medyanın anlatmayı düşünemediği hikâyeleri müşterileri adına bulup reklam 
kokmayan bir şekilde okurla buluşturmak yapılacak ișin merkezinde yer almaktadır (İzgi, 2014)". Kurumlar, transmedyal anlatımla hizmet, ürün ve faaliyetlerini hedef kitle ile paylaşarak onları olayın içine çekerler ve hikâyenin bir parçası haline getirirler.

Transmedya hikâye anlatımının markalaşma, halkla ilişkiler ve pazarlama için ikna edebilme, izleyici bağlantısı ve finansal etki gibi faydaları bulunmaktadır (Buckner ve Rutledge, 2011):

İkna Edebilme: izleyicinin zihnini sezgisel, duygusal ve yönetsel olarak harekete geçirebilen transmedya hikâyeleri, en temel ve en etkileyici iletişim şeklidir. Bilişsel, duygusal ve psikolojik olarak tüketicileri harekete geçirebilme motivasyonu iknayı kolaylaştırmaktadır.

İzleyici Bağlantısı: Transmedya hikâyeciliği stratejileri, müşteri veri tabanını etkin bir şekilde genişletmek için çok farklı demografik özelliklere sahip izleyicilere ulaşmayı sağlamaktadır. Farklı demografik özelliklere sahip olan ve birbiriyle bağlantı kuran izleyiciler, marka toplulukları veya fan gruplar oluşturarak hikâyenin içerisine dahil olmaktadirlar.

Finansal Etki: Transmedya hikâye anlatımı, yatırım getirisini yeniden tanımlamakta, markanın kendi yaşam süresini uzatmakta ve değerli varlıkları ile yardımcı gelir akışlarını artırmaktadır.

Yukarıda saydığımız faydalara iyi bir transmedya anlatımı ile ulaşmanın mümkün olduğunu göz ardı etmemekte fayda vardır. $\mathrm{Bu}$ etkilerin elde edilmesinden önce transmedya kampanyasını oluşturmak ve devamını sağlamak çok önemlidir. Bu noktada transmedya uygulayıcılarına büyük iş düşmektedir. Sutherland ve Barker (2014: 55-69), tarafindan yapılan çalışmada, transmedya uygulayıcı işverenler halkla ilişkiler okuyan öğrencilerin transmedya hikâyeciliği eğitimi almasını ve mezun olduktan sonra iş yerinde kullanmasını onları diğerlerinden ayrı kılacağını belirtmektedirler. Halkla ilişkiler mezunlarının medyaya yazabilme, geleneksel ve yeni medya aracılığıyla iletişim kurma becerisi ve teknik yeterliliğin önemli olduğunun belirlendiği çalışmada, sadece yeni medya platformları için nasıl içerik yazılacağı değil, aynı zamanda bu içeriklerin nasıl kullanılacağının da bilinmesi gerektiği vurgulanmaktadır.

Transmedya hikâyeciliği, yeni ve geleneksel medya kanalları üzerinden tek bir anlatımın iletişimi ile marka paydaşları ve tüketicilerini bu kurumsal hikâyeciliği ortak yaratıcıları haline getirmektedir ki bunun da kuruma dâhil olma hissini arttıracağına inanılmaktadır (Sutherland ve Barker, 2014:57). Transmedya hikâye anlatımı ile ulaşılması beklenen halkla ilişkiler hedeflerini şu şekilde sıralamak mümkündür (Silvia ve Anzur, 2011: 211):

$\checkmark$ Dikkatleri üzerine çeken marka hikâyelerinin sosyal medya başta olmak üzere birçok platformda işleyerek doğrudan hedef kitle ile irtibatta olmayı sağlamaktadır

$\checkmark$ Farklı medya kanallarında hikâyenin farklı bölümlerinin anlatımı ile bütüne izleyicilerin ulaşmasını sağlamak, aktif katılım sağlayan izleyicilerin marka ile daha çok bir araya gelmesi ile marka bilinirliğinin ve marka farkındalığının artmasıdır

$\checkmark$ Transmedya hikâye anlatımında medya platformlarının görsel, etkileşim ve kaynak açısından önemli özelliklerinin kullanılarak hikâyenin etkisini artırmak mümkündür

$\checkmark \quad$ Kitlenin heyecan seviyesini yükselterek, duygusal ve bilişsel çekicilikleri artırarak diğer medya platformlarında da hikâyenin ön plana çıkmasını sağlayarak haber değeri oluşturmaktır

$\checkmark$ Marka hikayesinin anlatımı ile marka felsefesini, marka kültürünü markanın vizyon ve misyonunu ortaya koyan bir anlatı şekliyle hedef kitlelerle marka arasında duygusal bir bağ kurarak uzun dönemli ilişkiler geliştirmektedir.

\subsection{Transmedya Hikâyeciliği Örneği Olarak "Turkcell Emocanlar"}

Pazarlama halkla ilişkileri, halkla ilişkilerden daha farklı bir boyut olarak ürünün ya da şirketin tanıtımının ötesinde amaçlara hizmet etmektedir. $\mathrm{Bu}$ amaçlar, marka bilincini arttırma, marka satışını arttırma, tüketici sadakatini oluşturma, eski ürün satışını yeniden canlandırma reklamın değerini ve etkinliğini arttırma, ikincil pazarlara ulaşma üretici firma güvenilirliğini ve ilgiyi hep canlı tutmadır. Kısaca pazarlama halka ilişkileri, bir yaşam tarzı ve pazarlama alanı olarak kendini göstermektedir. Pazarlanan yalnızca ürün veya hizmet değil, yaşam tarzı alışkanlıkları ve eğilimleri de beraberinde getirerek pazarı genişletmek ve ikincil pazarlar oluşturmak yolunda yapılan hem pazarlama teknikleri hem de halkla ilişkiler etkinlikleri bütünüdür (Büyükbaykal, 2012: 559).

Son zamanlarda pazarlama iletişimi ve halkla ilişkiler faaliyetlerinde kullanılan transmedya hikâyeciliğinin pazarlama halkla ilişkiler uygulamalarında da kullanılabileceğini söyleyebiliriz.

Jenkins (2016: 144) "transmedya hikâyesi, her biri bütüne farklı ve değerli bir katkıda bulunan yeni metinlerle çeşitli medya platformlarında ortaya çıkar. Transmedya hikâye anlatıcılığının ideal biçiminde, her bir yayın aracı en iyi yaptığı şeyi yapar; böylece bir hikâye bir filmde tanıtılır, televizyon, roman ve çizgi romanlarla genişletilir; dünyası oyun oynayarak keşfedilebilir veya eğlence parkı cazibesi olarak deneyimlenebilir" şeklindeki ifadelerine "Turkcell Emocanlar"'n uygun bir örnek olduğu görülmektedir. Nitekim Turkcell Emocanlar televizyon reklamlarını takiben sosyal medya, oyun ve oyuncak örnekleri eşzamanlı mecralar olarak ortaya çıkmıştır ve hikâye farklı platformlara sıçrayarak devam etmiştir.

Turkcell uzun yıllar marka yüzü olarak reklamlarında animasyon karakterleri "Cellocan"ları kullanmıştır. "Cellocan"ların yerine yeni kampanyasında emojilerden esinlendiği "Emocanlar"1 kullanmaya başlamıştır. Hedef kitlesini genişletmek isteyen ve sosyal medyayı aktif bir şekilde kullanan $Z$ kuşağının dikkatini çekmek için pazarlama ve halkla ilişkiler stratejilerinde şirketler emoji kullanımına başlamıştır. Özellikle bu yeni tüketici profilini pazarlama uzmanlarının çok iyi tanıması gerekmektedir. Transmedya hikâyeciliği de planlanırken hikâyesi, hedef kitlenin niteliklerine uygun olmalıdır. Kültürel yapısı ve 
özellikleri ile uyuşmalıdır (Çetinkaya, 2017: 574). Emocanlar Kampanyasını oluşturan reklam ajansı kreatif ortaklarından Emre Kaplan, katıldığı bir televizyon programında reklamlarda kullanılan anime karakterlerini yaratırken Türk halkından birilerini temsil eden, tanıdığımız ve gördüğümüz gibi karakterler olmasının çıkış noktalarından biri olduğunu belirtmiştir (www.haberturk.com, E.T. 21.08.2019).

\subsection{Emocan Karakterler ve Analizleri}

Turkcell, Emocanlar olarak adlandırdığımız karakterler ile birlikte tüketiciyi yeni bir dünyanın içerisine davet ederek, transmedya hikâye anlatıcılığı ile hedef kitlenin gönüllü katılımı ve katkılarıyla hikâyeyi genişletmiştir. Hikâye önce televizyon reklamlarında 6 emocan karakterinin tanıtımı ile başlamıştır. Kendine özgü özellikleri olan Emocanlar web sayfasında anlatılmıştır (www.turkcell.com.tr/emocanlar)

Görsel 2. Zeki Emocan

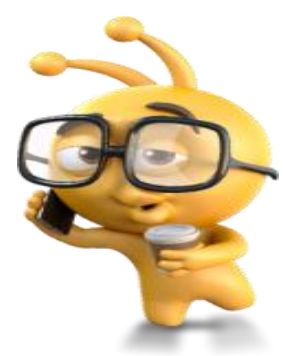

Kaynak:https://www.turkcell.com.tr/emocanlar

Zeki Emocan: Emocanlar'ın en akıllısı akıl küpüdür. Uzmanlık alanlarından sadece bir tanesidir Oyunculuk. Bildiği yabancı diller 7'den fazladır. Hesabını bilir, kaliteden ödün vermez. Karşılaştığı olay ne olursa olsun, onun mutlaka akıllıca bir çözümü vardır.

Görsel 3. Organik Emocan

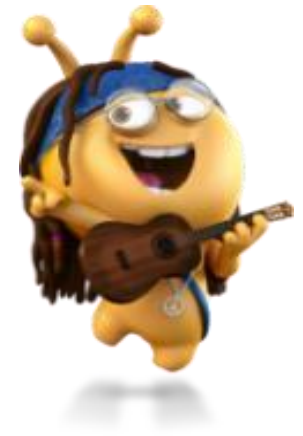

Kaynak: https://www.turkcell.com.tr/emocanlar

Organik Emocan: Emocanlar'ın en doğalı her şeyin doğalını sever. Kinoa ve avokado yemeyi, pilates ve yoga sporlarını sever. Astrolojiiye ilgi duyar ve duygularını gitarıyla dile getirmeyi çok sever.

Görsel 4. Racon Emocan

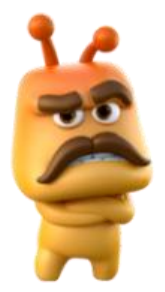

Kaynak: https://www.turkcell.com.tr/emocanlar

Racon Emocan: Emocanlar'ın ağır abisidir Racon. Babacan tavırlarıyla dikkat çeker, delikanlılıktan ve harbilikten asla ödün vermez. Ters durumları sevmez. Bilardo sporu ve tavla hobileri arasındadır. Maça gitmeyi sever.

Görsel 5. Sefa Emocan

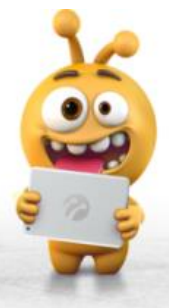

Kaynak: https://www.turkcell.com.tr/emocanlar

Sefa Emocan: Emocanlar'in en keyfine düşkünüdür. En yakın arkadaşları internet ve yemeklerdir. Dizi izlemeyi seviyor, yemek yemeyi daha çok seviyor. Dizi izlerken yemek yemeyi ise ayrı bir yere koyuyor. Üşengeç tavırlarıly dikkat çeker.

Görsel 6. Tistıs Emocan

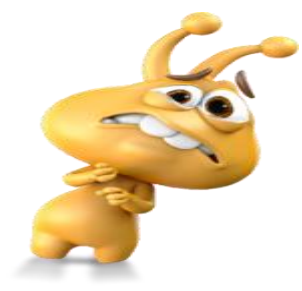

Kaynak: https://www.turkcell.com.tr/emocanlar

Tıstıs Emocan: Emocanlar'ın en korkağı, en endişeli ve ürkeğidir. İçinde bulunduğu durum ne olursa olsun, kendine korkacak geçerli bir sebep bulur. Boş zamanlarında televizyon izlemez; gözleri bozulabilirmiş. Karşısına çıkan hemen hemen her şeyden ürker fakat arkadaşları daima onun yanındadır.

Görsel 7. Pamuk Emocan

Kaynak:

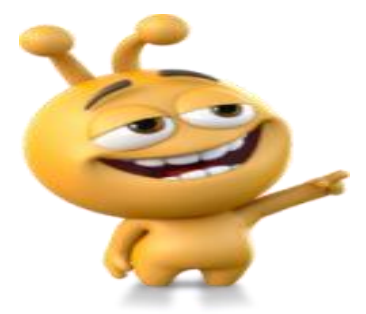

https://www.turkcell.com.tr/emocanlar

Pamuk Emocan: Emocanlar'ın en iyi kalplisi sevgi kelebeğidir. Tam bir Pollyanna'dır. Karşılaştığı olaylara hep pozitif tarafindan bakar. Sinemaya gitmeyi, müzik 
dinlemeyi, toplu taşımayla seyahat etmeyi... yani her şeyi sever, pek ayırmaz.

Görsel 8. Fikriye Emocan

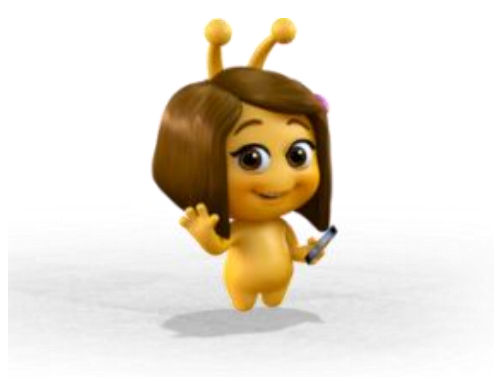

Kaynak: https://www.turkcell.com.tr/emocanlar

Fikriye Emocan: Turkcell, bu altı karakterin ardından internet sitesi üzerinden bir yarışma düzenlemiş ve müşterilerin oyları sonucunda Emocanlar'a kadın karakter Fikriye'yi eklemiştir. Emocanlar'in en parlak fikirlisi olarak tanıtılan Fikriye, aynı zamanda tam bir sosyal medya canavarıdır. Nerede olursa olsun, telefonu hiç elinden düşmez. Gündemi takip eder ve popüler şeyler ondan sorulur. Instagram ve Twitter'daki paylaşımları, binlerce "like" alır (www.campaigntr.com).

Turkcell'in bu yeni emojisi, Emocanlar'ın ilk dişil/kadın karakteri olma özelliğiyle dikkat çekmekte ve Turkcell'in yenilediği iletişim stratejisini yansıtmaktadır. Hazırlanan bu dijital video reklamı, yarışma süresince Youtube'da yayın içi reklam olarak oynatılmış ve tüketiciler yarışma sayfasına yönlendirilmiştir (Güven, 2018: 87).

Turkcell Emocanlar kampanyası ilk olarak televizyon, gazete gibi geleneksel iletişim araçlarını kullanarak reklam çalışmaları gerçekleştirilmiş ve bu araçlar aracılığıyla tüketiciler sosyal medya kanallarına yönlendirilmiştir. Tüketicilerin emocanlarla buluştuğu reklamlar ile izleyici emocanların dünyasına çekilerek marka ve marka hizmetleri hakkında tüketicilere bilgiler verilmiştir. Bir transmedya hikâyeciliği örneği olarak reklam kampanyasında uygulanmıştır.

Görsel 9. Turkcell Emocanlar Televizyon Reklamından Bir Sahne

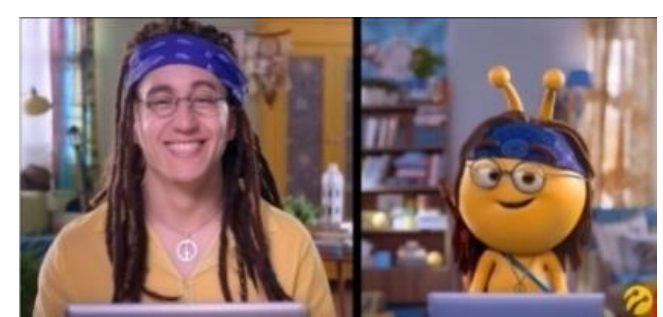

Kaynak: www.youtube.com (E.T.: 21.08.2019)

Emocanlar reklamlar dışında da televizyon ekranlarında izleyici ile buluşmuştur. Racon Emocan NTV Spor kanalında Güntekin Onay'ın sunucusu olduğu futbol programına konuk olmuştur. Transmedya hikâye anlatımı uygulamaları ile ilgi alanları doğrultusunda farklı tüketici gruplarının katılımını sağlayacak platformdan yararlanılmıştır. $\mathrm{Bu}$ sayede marka farklı hedef kitlelerine ulaşmıştır.

Görsel 10. Racon Emocan NTV Spor Programında Yorumculuk Yapıyor

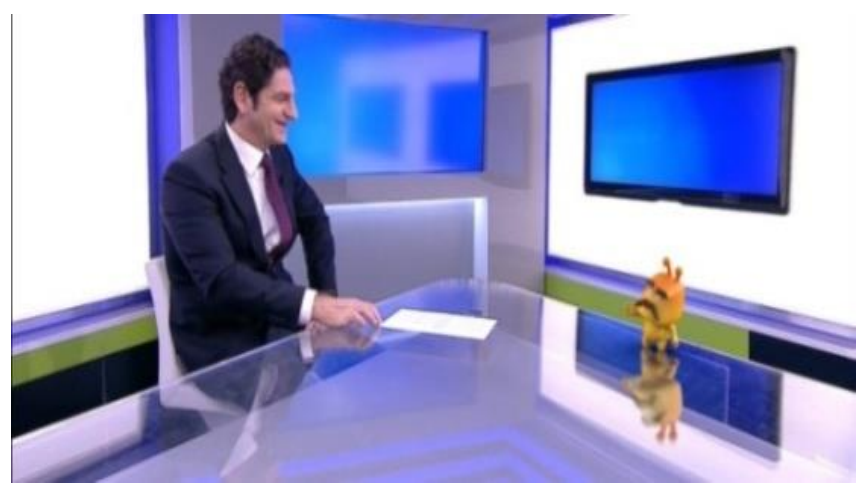

Kaynak: https://vimeo.com/23823271 (E.T.: 21.08.2019)

Kampanya kapsamında takipçilerin online olarak emocanları yakından tanıyabilecekleri bir ortam www.turkcell.com.tr/ emocanlar internet sitesi bulunmaktadır. Web sitesi bilgilendirme dışında her bir reklam karakterinin burçları yorumladığı eğlenceli içerikler ve 'emocanlarla selfie' gibi kullanıcı katılımına olanak tanıyan interaktif bir ortam oluşturulmuştur.

Görsel 11. Web Sayfasında Emocanların Burçları Yorumlaması ve 'Emocanlarlaselfie'

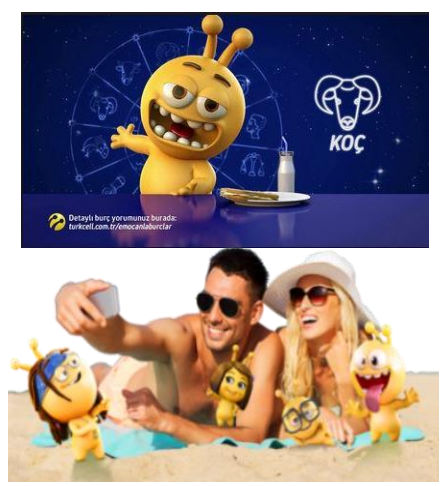

Kaynak: https://www.turkcell.com.tr/emocanlar

Transmedya anlatıcılığında hikâyenin ulaştığı kişilerin hikâyenin yalnızca izleyicisi değil aynı zamanda hikâyeye katkıda bulunarak gelişmesine, farklılaşmasına yeni açılımlara girişmesine tesir eden temel unsur olması önemli bir meseledir. Bu hususta genel olarak sosyal medya ve daha özelde sosyal ağ siteleri sahip olduğu alt yapı gereği, kullanıcısına sunduğu içerik üretme ve üretilen içeriğe katkıda bulunma gibi nedenlerden transmedyal anlatı bakımından uygun bir zemin hazırlamaktadır (Aktan, 2018: 33). 
Turkcell'in Emocanları facebook, twitter, instagram, youtube, ekşi sözlük, onedio vb. Sosyal ağlarda da tüketicinin karşısına çıkmaktadır. Bu durum sosyal medya ortamlarının üretilen transmedyal anlatıya ve transmedya evrenine daha kolay dahil olabilmesi ve kullanıcıların içeriğe kendi yapacağı katkı ve yorumlar ile destek olmasına imkân vermektedir. Böylece transmedya anlatısı, sosyal ağlar arasında bölünerek genişleyen ve güçlenen bir yapıya bürünebilmektedir.

Hayran kitlesi tarafından emocanlar için çizgi filmler oluşturulmuş, yapılan emocan şarkıları ile çocukların sayı saymayı, renkleri vb. öğrenebilecekleri videolar Youtube'da oluşturulmuştur. Bu sayede hikâyeyi genişleten tüketiciler aynı zamanda kendisine yakın bulduğu emocan karakteri ile hikâyeye katkıda bulunmuştur. Sosyal ağlar, transmedyal anlatı çerçevesinde takipçi etkinliğini artırıcı ve genişletici etkiye sahiptir.

Görsel 12. Sosyal Medyada Emocanlar

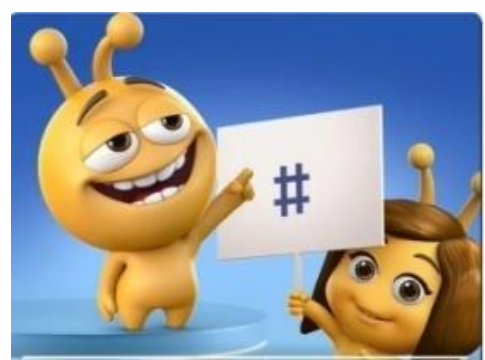

Kaynak: twitter.com/Turkcell (E.T.: 21.08.2019)

Akıllı telefonlar üzerinden mesajlaşma, görüntülü konuşma vb. imkânlar sunan uygulamalar haberleşme kanalı haline gelmiştir. Özellikle kullanıcılarını gençlerin oluşturduğu eğlenceli sticker ve caps'ler oluşturma, kaybolan mesaj özelliklerinin yanı sıra keşfet platformu içerisinde kullanıcıların ilgilerine göre takip edip haber alabilecekleri birçok uygulama oluşturulmuştur. Yaygın olarak kullanılan bir uygulama olan Snapchat vb. (www.youtube.com) Uygulamalarda Emocan filtreleri oluşturulmuş, Turkcell'in kendi oluşturduğu BIP uygulamasında Emocan stickerları vs. yer almıştır (medya.turkcell.com.tr).

Görsel 13. Mobil Uygulamalar ve Emocanlar

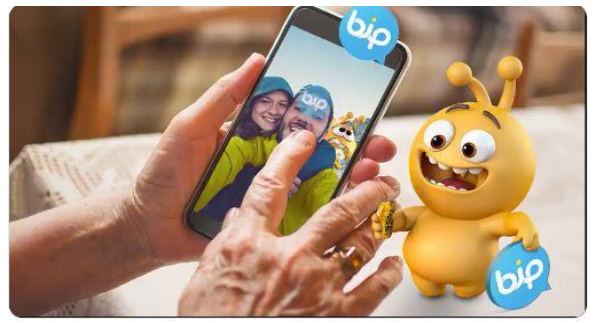

Kaynak: twitter.com/Turkcell (E.T.: 21.08.2019)

Son yıllarda dijital oyunların da transmedya hikâyeciliği ile iç içe girdiği görülmektedir. Özellikle gençler gerek internet cafe olsun gerekse dizüstü bilgisayarlar veya cep telefonunda gün içerisinde saatlerce dijital oyun oynamaktadır. Oyun içerisindeki kahramanların özellikleri, oyunun kendine ait hikâyesi, günlük, haftalık, aylık görevler oyunun avatarları gençler tarafindan benimsenmektedir. Oyun ve transmedya hikâyeciliği uygulamaları insan ve iletişim araçları arasında önemli bir etkileşim gerçekleştirmektedir (Çakmak, 2018, s. 70-71).
Turkcell Emocan kampanyası da oluşturulan dijital oyun ile hikâyeye katkı sağlamaktadır. Bilgisayar, tablet ve akıllı telefonlar üzerinden oynanabilen 'Emocan Matching' oyunu ile tüketiciler emocanların eğlenceli dünyası ile tanışmıştır. Bununla da sınırlı kalmayarak site ve forumlar üzerinden yorum yapan oyuncular oyun hakkında görüşlerini birbirleri ile paylaşmaktadır. Turkcell'in oluşturduğu Bip uygulamasında da emocanlar kullanıcılara oyun olarak sunulmaktadır.

Görsel 14. Mobil Oyun uygulaması ve Emocanlar

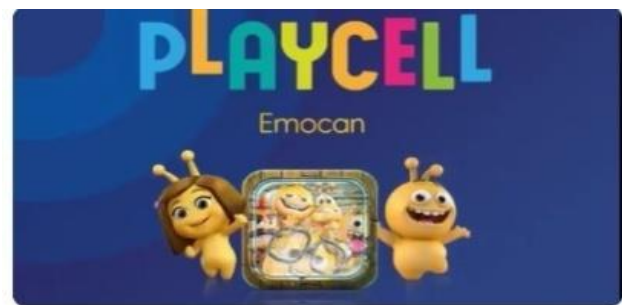

Kaynak: twitter.com/Turkcell (E.T.: 21.08.2019)

Markanın tasarladığı dijital oyunlar, aksesuarlar, reklam karakterlerinin oyuncak figürleri ve diğer ürünleri kullanarak, kampanyayı kullanıcıların pasif olarak izleme boyutundan çıkarıp günlük hayatlarının bir parçası haline getirdikleri görülmektedir. Görselde de görüldüğü gibi tüketiciler emocanları kendi hesaplarında da paylaşmış ve aralarında reklamlardan öte bir bağ oluşmuştur. Fotoğrafin altına gelen yorumlarda da kişinin Racon Emocanla benzetildiği ve buna benzer birçok tepkinin oluştuğunu söyleyebiliriz. Emocanların transmedyal anlatısı planlanırken tiplerin halka benzer yönde oluşturulması anlatı stratejisini başarılı hale getirmiştir. Ve transmedya hikâyeciliğin tipik özelliklerinden birini oluşturmaktadır.

Görsel 15. Tüketici ve Emocan Oyuncak Etkileşimi Örneği

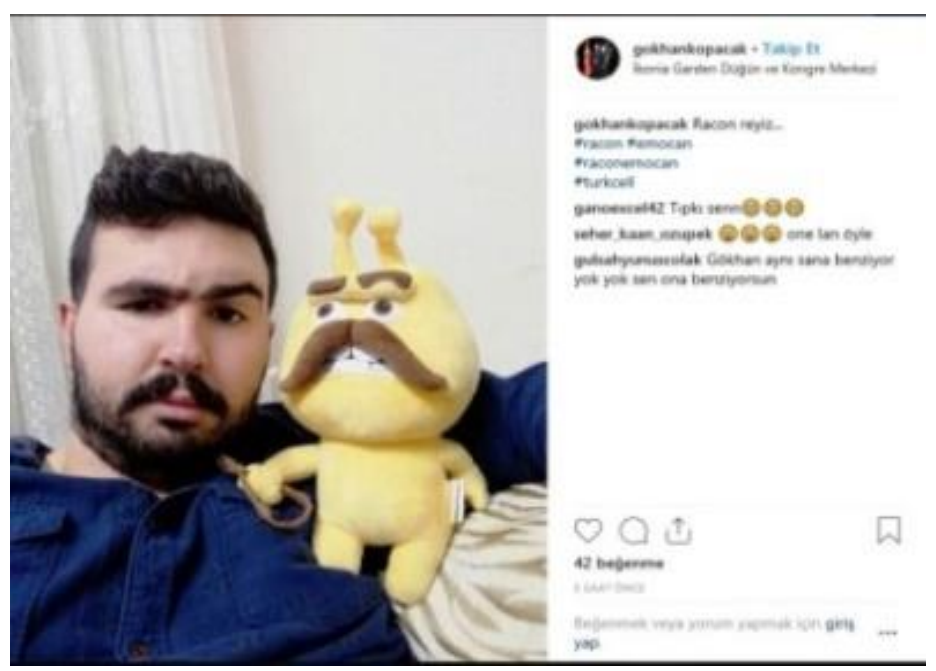

Kaynak: http://twitter.com (E.T.: 21.08.2019)

Tüketicilerin dikkatlerini bir konuya yöneltmek ve oluşturulacak hikâyelerle hedef kitleleri cezbederek ürün ya da hizmetin çekim alanında tutmak için transmedya kullanımı en ideal yollardan biri haline gelmiştir (Sezen, 2014: 42). Özellikle firmaların topluma karş1 sorumluluklarının artmasıyla hikâyenin farklı medyalar 
üzerinden aktarılmasını sağlayan transmedya hikâyeciliği Kurumsal Sosyal Sorumluluk uygulamalarında da kullanılmaktadır (Fidan, 2018: 178). Çalışmamızın konusunu oluşturan Turkcell firması da yaptığı sosyal sorumluluk projelerine emocanları dâhil ederek kampanyanın evrenini genişletmiştir. Organik Emocan'ın karakterine uygun olarak 'Turkcell'in Sıfır Atık' başlıklı sosyal sorumluluk projesinde yer alması kurumsal sosyal sorumluluk içerisinde transmedya anlatının kullanımına örnektir.

Görsel 16. Sosyal Sorumluluk projesinde Emocanlar

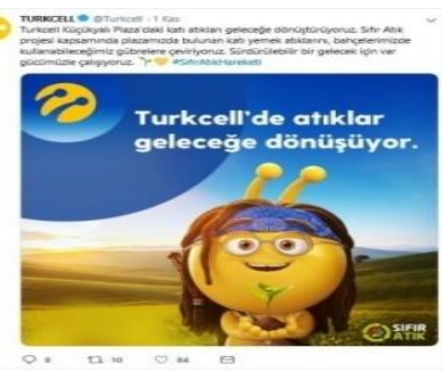

Kaynak: twitter.com/Turkcell (E.T.: 21.08.2019)

Transmedya hikâyeciliğinde daha öncede belirtildiği gibi amaç, bir hikâyenin birden fazla medya aracına bölünerek aktarılmasıdır. $\mathrm{Bu}$, takipçilerin hikâyenin geri kalan kısmı için bir mecradan diğerine geçiş yapmasını sağlar. $\mathrm{Bu}$ süreçte hikâyede kopmalar yaşanmamakta aksine takipçilerin sürece dâhil olmasına da yol açmaktadır. $\mathrm{Bu}$ akış içerisinde farklı mecraları tecrübe eden takipçiler, her tecrübe ettiği mecrada hikâyenin farklı bir boyutunu keşfetmekte ve hikâye evreni içerisine girmeye daha hevesli olmaktadır. Aslında hikâye evrenine dâhil olan takipçiler hikâyeyi kendi katılımlarıyla inşa etmektedir denilebilir (Dönmez ve Güler, 2016:157).

Emocanlar kampanyası da daha önce belirttiğimiz gibi çeşitli platformlarda kullanılmakla birlikte Ekşi sözlük ve Onedio gibi platformlarda da yer almıştır. Özellikle Onedio da kendi içeriklerini oluşturmuşlardır ve kullanıcılar emocanlarla ilgili tüm haberler, içerikler, galeriler, testler ve videolara ulaşmışlardır. Tüketici dâhil olduğu birçok platformda kendi katkısıyla kampanyayı genişletebilmekte hatta seyrini değiştirebilmektedir.

Görsel 17. Onedio web sitesinde Emocanlar

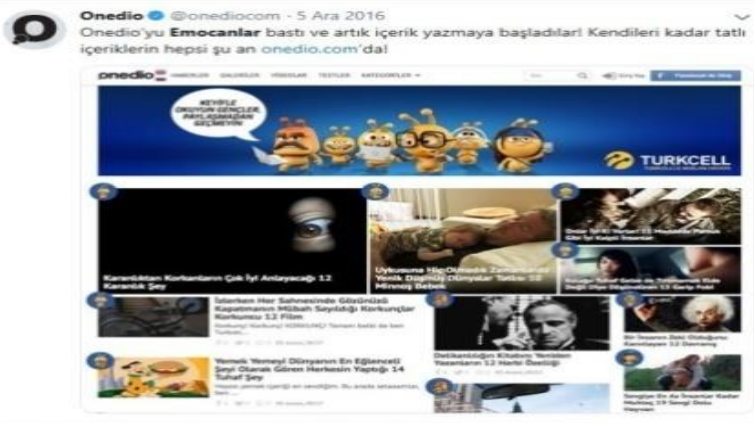

Kaynak: twitter.com/Turkcell (E.T.: 21.08.2019)

Turkcell'in emocanları kullanarak oluşturduğu bir yapılanma da 'Sürpriz Nokta'. Bu kanalla Turkcell kullanıcıları, mobil cihazlarından dijital oyun oynayarak harita üzerinde belirtilen konumlarda saklanmış emocanlar ve çeşitli hediyeleri birlikte bulmuşlardır. Takipçiler gönderilen görevleri yerine getirerek interaktif bir şekilde katılım sağlamışlardır. Bu sayede transmedyal anlatı ile tüketicilerin aktif olarak katılımı sağlanmış ve katılım sonunda ödüllendirilmiştir (www.chip.com.tr (E.T.: 21.08.2019)

Görsel 18. Emocanlar ve Sürpriz Nokta Uygulamas1

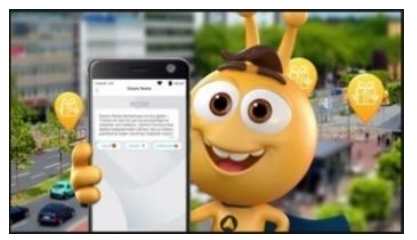

Kaynak: twitter.com/Turkcell (E.T.: 21.08.2019)

Emocanlar hayranları ile buluşmak, çocuklarla eğlenmek, çeşitli uygulamalar ve imkânları takipçileriyle paylaşmak için birbirinden farklı etkinlikler yapıp, Kıbrıs vb. yerlere geziler yapmışlardır.

\section{Görsel 19. Emocanlar Etkinlik}

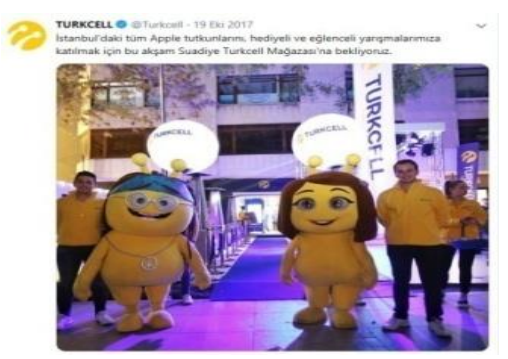

Kaynak: twitter.com/Turkcell (E.T.: 21.08.2019)

\section{Sonuç}

Çağımız insanı, her gün çıkan yeni ürünler, bunlar için yapılan reklamlar, pazarlama çalışmaları sonucu doğan iletişim ortamında adeta kaybolmaktadır. Ürün sahipleri de bu nedenle hedefleri olan tüketicilere ulaşmak için yeni yollar denemekten kendilerini alıkoyamazlar. Amaç ürünü veya hizmeti diğer ürünlerden daha ön plana çıkartıp sattırmaktır. Pazarlama çalışmaları da, reklam çalışmaları da doğrudan olmasa da halkla ilişkiler çalışmaları hep bu yeni iletişim yollarını ve mesajları yaratmaya uğraşırlar. İletişim platformlarının her geçen gün çeşitliliğin artması ve markaların hedef kitleleri ile farklı yöntem ve tekniklerle iletişim kurmaya yönelmeleri transmedya hikâye anlatımının önem kazanmasını ve etkili bir pazarlama halkla ilişkiler stratejisi olmasını sağlamaktadır.

Transmedya hikâye anlatımının, kitap, reklam, film, dizi ve oyun örneklerinde karşımıza çıktığı çalışmaların -bkz. Sarı (2017), Dönmez ve Güler (2016), Koçyiğit (2018), Çakmak (2018), Nizam ve Çalık (2018)- aksine bu çalışmada transmedya pazarlama halka ilişkiler bağlamında incelenmiştir. Daha önce transmedya ve halkla ilişkiler alanı üzerinde yapılmış çalışmalarda ise bazen halkla 
ilişkilerin alanına giren sosyal sorumluluk, şehir tanıtımları ve sponsorluk kapsamında incelemelerin yapıldığı fakat reklam konusunun incelenmediği görülmüştür. Çalışmamız bu noktada farklılaşmakta ve pazarlama halkla ilişkiler kapsamında transmedyal anlatının reklam kampanyasında uygulanma biçimini analiz etmektedir.

Çalışma sonucunda elde edilen bulgulara göre; Turkcell markası Emocanlar kampanyası ile tüketicilerin dikkatini çekme amacına ulaşmıştır. Marka, geleneksel iletişim ve halkla ilişkiler stratjilerini kullanmaya devam etmekle birlikte, dijital medya teknolojilerinin gelişimi ile hedef kitlelerine hikâyeler aracılığıyla ulaşmakta, onları eğlendirmekte, katılım sağlamakta ve deneyimler sunmaktadır. Marka deneyimleri, tüketicilerin marka ile etkileşimini artırmakta, marka özellikleri ile kişisel özelliklerini bütünleştirerek marka ile duygusal bir bağ kurmasını sağlamaktadır. Transmedya hikâye anlatımı stratejisinde, tüketicinin hikâye ile aktif etkileşim halinde olması, marka deneyimi ile birlikte, marka kimliğini ve imajını güçlendirmekte, marka bilinirliğini ve marka farkındalığını da arttırmaktadır.

Çetinkaya (2017)'nın çalışmasında bahsettiği planlanacak transmedya hikâyesinin hedef kitlenin niteliklerine uygun olması gerektiği ve hedef kitlenin kültürel yapısı ve özellikleri ile uyuşması gerektiğine çalışmamızın analiz kısmında değinilmiştir. Farklı olarak oluşturulan karakterlerinde önemi ortaya koyulmaya çalışılmıştır. Nitekim Turkcell Emocan kampanyasında Türk halkına benzer karakterde tiplerin oluşturulması, son zamanlarda popüler olan ve sempati duyulan emojilerin sokaktaki insanlara uyarlanarak bir tip haline getirilmesi tüketicilerin hikâyeyi daha kolay sahiplenmesini sağlamıştır. Rakiplerinden sıyrılarak dikkat çeken markanın yaptığı bu kampanya ile Marka İletişim Direktörü Dilara Demir Kısakürek, yaptıkları testlere göre 10 kişiden 9'unun emocanları çok sevdiğini, 10 kişiden 7'sinin de Turkcel'le ilgili artık daha olumlu şeyler hissettiğini söylemiştir (https://www.haberturk.com/ medya/haber/1342887-turkcellin-emocanlari-reklamarkasinda E.T.10.8.2019).

Emocan kampanyası ile geleneksel ve dijital iletişim araçları kullanılmış, istenmeyen ve gereksiz marka mesajlarıyla hedef kitleleri bombalamak yerine, kitleleri ilgi çekici, markayla hedef kitle arasında doğrudan etkileşimi artıran ve kitleleri hikâyenin bir parçası haline getiren anlatılar sayesinde, tüketicilerle birçok farklı kanaldan etkileşime geçilmiştir. Aynı zamanda farklı hedef kitlelerine uygun araçlar kullanarak örneğin; emocan mobil oyunu ve peluş oyuncakları ile hedef kitlesini genişletmişstir.

Kampanya ile birlikte takipçi/tüketicilere çeşitli görevler verilerek ödüllendirilmesinin yanı sıra gerçek hayatla kurgusal dünyayı birleştirerek günlük hayatında deneyimlenmesi sağlanmıştır.

Yukarıda belirtilen sonuçlardan da yola çıkarak çalışmamızın temelini oluşturan varsayımların doğrulandığı görülmektedir.

\section{Kaynakça}

Akbaba Resuloğlu, F. (2014). Yakınsama Kültürü ve Transmedya Hikâye Anlatımı Uygulamaları Üzerine Bir Çözümleme: Propp'un İşlevler Kuramı ve Taht Oyunlarl (Game Of Thrones) Dizisi. Yüksek Lisans Tezi, Kocaeli Üniversitesi

Aktan, E. (2018). Sosyal Ağlar ve Transmedya Hikâyeciliği: Kullanıcı Paylaşımları Üzerinden Transmedyal Hikâye Etkinliğinin Değerlendirilmesi. (Ed. Aktan, E.) Halkla İlişkilerden Reklama, Sosyal Medyadan Turizme: Transmedya Hikâyeciliği. Konya: Literatürk Academia.

Aytemur, S. (2012). Hikâye Oksijendir. İstanbul: Medicat Yayınları.

Bayraktar, S. (2018). Moda Sektöründe Transmedya Hikâye Anlatımı: Barbie Bebek Transmedya Uygulamaları Örneği. Erciyes İletişim Dergisi.

Bolat, N. (2018). "Fatmagül'ün Suçu Ne? Anlatısının Transmedya Hikâye Anlatıcılığı Bağlamında İncelenmesi. E. Aktan içinde, Halkla Illişkilerden Reklama, Sosyal Medyadan Turizme: Transmedya Hikâyeciliği. Konya: Literatürk Academia.

Buckner, B ve Rutledge, P. (2011). Transmedia Storytelling for Marketing and Branding: It's Not Entertainment, It's Survival. http://www.kcommhtml.com/ima/2011_03/transmed ia_storytelling (E.T. 06.7.2019)

Büyükbaykal, G. N. (2012). Pazarlama Halkla İlişkileri Nedir? İstanbul Üniversitesi İletişim Fakültesi Dergisi | Istanbul University Faculty of Communication Journal .

Çakmak, V. (2018). Dijital Oyunlar ve Transmedya Hikâyeciliği. E. Aktan içinde, Halkla Illişkilerden Reklama, Sosyal Medyadan Turizme: Transmedya Hikâyeciliği. Konya: Literatürk Academia.

Çetinkaya, Ö. A. (2017). Marka Sadakati Oluşturma Aracı Olarak Transmedya Hikâye Anlatımının Yeri ve Değeri. Manas Sosyal Araştırmalar Dergisi, 559576.

Dönmez M, (2015). Pazarlama Iletişiminde Transmedya Uygulamaları: Örnek Olay Incelemeleri, Yüksek Lisans Tezi, Selçuk Üniversitesi

Dönmez, M., \& Güler, Ş. (2016). Transmedya Hikâyeciliği "Doritos Akademi" Örneği İncelemesi. Süleyman Demirel Üniversitesi Vizyoner Dergisi.

Duğan, Ö. (2018). Transmedya Hikâye Anlatımının Halkla İlişkilerde Kullanımı. (Ed. Aktan) içinde, Halkla Ilişkilerden Reklama, Sosyal Medyadan Turizme: Transmedya Hikâyeciliği. Konya: Literatürk Academia.

Engin, E. (2013). Fisher'ın Anlatı Paradigması Bağlamında Kurum Hikâyeleri Üzerinden Kurumsal Değerlerin Anlamlandırılması: Bir Anlatı Analizi, Doktora Tezi, Marmara Üniversitesi.

Fidan, Z. (2018). Kurumsal Sosyal Sorumluluk ve Transmedya. Ed. Aktan içinde, Halkla İlişkilerden 
Reklama, Sosyal Medyadan Turizme: Transmedya Hikâyeciliği. Konya: Literatürk Academia.

Gürel, E., ve Tığlı, Ö. (2013). Sosyal Medyayla Yaratılan Yeni Dünya: Transmedya Anlatım. C. Bilgili içinde, Sosyal Medya ve Ă̆ Toplumu 1: Kitle Illetişiminde Yaşanan Değişimler. İstanbul: Grafik Tasarım Yayıncilık.

Güven, G. Ö. (2018). Dijital Çağın Eğlenceli Dili Emojiler: Reklamcılıkta Emoji Kullanımları Üzerine Bir Değerlendirme. Halkla Illişkiler ve Reklam Çalışmaları E-Dergisi.

İpekli, Y. (1994). Pazarlama Karışımı İçinde PR. Marketing Türkiye Dergisi.

İzgi, H. İ. (2014) https:// https://medium.com/storytellingyaz-lar/halkla-iliskilerin-gelece-i-ve-storytellingb8f876f7e777 E.T:1.9.2019.

Jenkins, H. (2003). 'Transmedia storytelling: Moving characters from books to films to video games can make them stronger and more compelling', MIT Technology Review, https:// www. technologyreview.com /s/ 401760/ transmediastorytelling/ E. T.: 02.08.2019.

Jenkins, H. (2006). Convergence Culture - Where Old and New Media Collide, New York University Press.

Jenkins, H. (2016 ). Cesur Yeni Medya: Teknolojiler ve Hayran Kültürü. (İ. İ. Nihan Yeğengil, Çev.) İstanbul: İletişim Yayınları.

Karc1, H. D. (2018). Markalaşma ve Transmedya Hikâyeciliği: Bir Uygulama Örneği. Doktora Tezi, Selçuk Üniversitesi.

Karpuz, A. (2017) Transmedya Markalama ve Etkileşimli Reklam Iliş̧kisi Yüksek Lisans Tezi, Marmara Üniversitesi.

Kaya, İ. (2014). Pazarlama Bi Tanedir! İstanbul. : Babıali Kültür Yayıncılığg1.

Koçyiğit, A. (2018). Transmedya ve Dijital Reklam Anlatısı. E. Aktan içinde, Halkla İlişkilerden Reklama, Sosyal Medyadan Turizme: Transmedya Hikâyeciliği. Konya: Literatürk Academia.

Koçyiğit, M. (2018). Dijital Çağın İletişim Sanatı: Transmedya Hikâyeciliği ve Dijital Halkla İlişkiler. E. Aktan içinde, Halkla Iliş̧kilerden Reklama, Sosyal Medyadan Turizme: Transmedya Hikâyeciliği. Konya: Literatürk Academia.

Nizam, F., \& Çalık, M. (2018). Transmedya Hikâyeciliği Bağlamında 'Söz' Dizisinin Analizi. E. Aktan içinde, Halkla İlişkilerden Reklama, Sosyal Medyadan Turizme: Transmedya Hikâyeciliği. Konya: Literatürk Academia.

Patton, M.Q. (2015). Qualitative Research and Evaluation and Methods- Integrating Theory and Practice (4th ed.). Thousand Oaks, CA. Sage Publications.

Pratten, R. (2015). Getting Started with Transmedia Storytelling: A Practical Guide for Beginners. CreateSpace Independent Publishing Platform.

Ramazanov Huseynoğlu, R. (2016).“Transmedya Hikâye Anlatımının Kullanıc Kitle Ile Ortak Üretimi: Beyazıt Akman'in "Imparatorluk III" Romanının Tanıtım Filmi”, Yüksek Lisans Tezi, İstanbul Beykent Üniversitesi.

Sarı, G. (2017). Transmedya Hikâye Anlatıcılı̆̆ı: Kötü Çocuk örneği. Abant Kültürel Araştırmalar Dergisi (AKAR) , 71-79.

Scolari, C. A. (2009). Transmedia Storytelling: Implicit Consumers, Narrative Worlds, and Branding in Contemporary Media Production. International Journal of Communication.

Sezen, D. (2014). Transmedya Hikâyeciliği. (Ed. S. Karaçor, D. Aydın \& A. Gülerarslan) içinde, Transmedya Hikâyeciliği. Konya: Çizgi Kitabevi.

Silvia, T., ve Anzur, T. (2011). Power Performance Multimedia Storytelling For Journalism And Public Relations. Wiley \& Sons, Ltd., Publication.

Sutherland, K., ve Barker, R. (2014). The Influence of Transmedia Storytelling Portfolio Examples on Employer Perceptions of Public Relations Graduate Employability- A Pilot Study. Asia Pacific Public Relations Journal | Vol. 15, No. 1.

www.turkcell.com.tr/emocanlar E.T. 21.8.2019

https://www.haberturk.com/medya/haber/1342887turkcellin-emocanlari-reklamarkasinda E.T.10.8.2019

https://www.campaigntr.com/E.T. 21.8.2019

https://vimeo.com/23823271 /E.T.21.08.2019

https://www.chip.com.tr/haber/bip-ile-hediye-avina-ciksurprizleri-kazan_75508.html/ E.T.21.08.2019

https://www.youtube.com/watch?v=LM_qCktK6v8 E.T. 12.8.2019

https://twitter.com/Turkcell/E.T.21.08.2019 